\title{
The Perspective of Forestry Graduates Toward Rural Forestry Based Business
}

\author{
Anita Hafsari ${ }^{1^{*}}$, Bahruni ${ }^{2}$, Dudung Darusman ${ }^{2}$ \\ ${ }^{1}$ Graduated School of Bogor Agricultural University, Dramaga Main Road, Campus IPB Dramaga, Bogor, Indonesia 16680 \\ ${ }^{2}$ Department of Forest Management, Faculty of Forestry, Bogor Agricultural University, Academic Ring Road, Campus IPB \\ Dramaga, PO Box 168, Bogor, Indonesia 16680
}

Received February 10, 2015/Accepted April 30, 2015

\begin{abstract}
The rural forestry business had shown good economic feasibility and worthed to develop in the rural economy. However, the current fact showed that the output of this business seemed to fail even the proper living standards and therefore became unattractive. The attractiveness issue could be answered by increasing the business profitability through the role of forestry graduates as the main actors of forestry business. Forestry graduates in Indonesia, with their title as Sarjana Kehutanan (S.Hut) had been scarcely involved in rural and traditional forestry based business. Such anomaly had not been becoming neither governmental nor profesional concerns. This study tried to explore the perspective of the S.Hut, concerning their understanding and interest in the business, to see how far their potential capacity to be entrepreneurs. This study differentiated the respondences into S.Hut working in forestry and S.Hut working in non-forestry job. With qualitative and quantitative approach, and total respondents of 158 persons, consisting 122 persons as forestry jobs and 38 persons as non-forestry jobs, this study found out that the S.Hut in Indonesia had ample or good perspectives based on the parameters of higher interests, attractiveness, knowledge, and effications. It meant that they were worthed to be involved as the business entrepreneurs.
\end{abstract}

Keywords: forestry graduates, perspective, rural forestry based business

*Correspondence author, email: anitnita29@gmail.com,tel.+62-81211605910

\section{Introduction}

The rural forestry business had been traditionaly managed by rural people, either personally or communally, utilizing many kind of benefits from forest ecosystems, as raw material as well as products of small scale industry. Such kinds of business management, referring to the forest ecosystem management, had been expected to contribute significant economic welfare to the community, as well as to the sustainability of forest ecosystem (Suhendang 2013). The Indonesian Government has been allocating 5.6 million ha of forest land (MoF 2011) to develop such rural forestry based business, but so far it had been developed only 184,400 ha or $3.3 \%$ (Suharjito 2014). The kinds of the expected forestry based business could be in the form of privately managed forest (HR or HTR), community nursery (KBR), community forest $(\mathrm{HKm})$, and village forest $(\mathrm{HD})$.

The rural forestry based business as part of rural economy (Hardjanto 2003) had been utilizing natural resource to be livelihood (Hossain 2000), and according to Andrew and Omobude (2011) the rural economy has 5 major components, such as human resources, natural resources, primary production, agricultural, and non-agricultural activities. Generally the rural forestry business had shown good economic feasibility and worthed to develop in the rural economy, at least based on many research conducted in many places, such as in Bogor (Hardjanto et al. 2012), Ciamis
(Ahmad \& Purwanto 2014), Maluku (Salaka et al. 2012), Riau (Rochmayanto \& Supriadi 2012), Lampung (Wulandari et al. 2014), and Sulawesi (Wurangian \& Putra 2013).

Human resources had been a very crucial factor in developing business, and needed to be addressed in this research. The development of forestry business, even further on bigger scale would need better and stronger professionality. Forestry business requires a forestry spirit of long-term character. Therefore, the development of forestry business, which had to be integrated with professional development should be very important. This research would like to know about the readiness of Sarjana Kehutanan (S.Hut) to be forestry entrepeneurs.

The involvement of S.Hut in rural forestry based business had been very scarce, and out of governmental concerns, neither on formal education nor on suitable business development programs. The curricula of formal forestry educations had tent to produce graduates ready to work (job seekers) rather than ready to create job (job creators). At the meantime, present and future business would relly on knowledge and intelectual capital, so that to improve business competitiveness should relly on well educated and trained young entrepreneurs. Entrepreneurs are people who dare to take risks, independent-minded, and dare to start a business on any opportunities (Kashmir 2006). University graduates should be encouraged and fostered to have the 
spirit of entrepreneurship (Suharti \& Sirene 2011). It had been a low tendency of S.Hut working as entrepreneurs, for instance, alumni office (DPKHA) of IPB had recorded that about $97.2 \%$ of forestry 2009-2012 graduates working for private company and govermental offices, and only $2.8 \%$ of the graduates were working as forestry entrepreneurs. It had been a need to study and explore the perspective of S.Hut, as a key factor for entrepreneurial development. Adopted from Storey (1910), perspective can be defined as point of view of someone on self perception about business. The perspective can be influenced by internal and external factors (Suharti \& Sirene 2011), and the internal factors come from individual characters, and influenced by socio-demographic factors, such as pre-natal factor of age, gender, and educational background (Nishanta 2009; Nimalathasan \& Achchuthan 2013; Thung 2014). While the external factors come from outside the individual or environmental factors, such as the workplace and family environment (Galloway \& Kelly 2009; Suharti \& Sirene 2011). Both internal and external factors should be analyzed to see the potential capacity of S.Hut to become foretry entrepreneurs (Praswati 2014).

This study would like to find out how far the perspective of the S.Hut could be develop to support the development rural forestry based business. It is expected that the S.Hut give greater involvement and contribution to the rural economy not only in term direct income and employment but also it is multiplier effects to the rural economy.

\section{Methods}

The research was conducted in September to December 2014 with 158 respondents (S.Hut). The research differentiated of S.Hut working in forestry (S.Hut forestry) and those in non forestry (S.Hut non forestry), focusing on perspective their understanding and interest in the business. Research analysis of the perspective were develop based on the concept of selfefficacy by Bandura (1986). Self-efficacy is a person's beliefs about their ability to do something (Bandura 1986; Baron \& Byrne 2000; Brown et al. 2005). The context of something in this study was to becomes entrepreneurs or self-confidence to become entrepreneurs. Thats, self effication is influenced by mastery and vicarious experience, verbal persuasion, and psychological conditions (Brown et al. 2005). The research collected data and information of (1) characteristics of the respondents, (2) perspective of their understanding on rural forestry business: potential and opportunities market of forest products, forestry business position compared to other sectors, the main actors in forest management, business scale and a willingness to collaborate with the community, (3) perspective of their self potential to becoming entrepreneurs: interest, attraction, knowledge, and capacity to develop the business. This research using a qualitative approach as well as quantitative approach. The qualitative approach described the perspective which was analyzed by Likert scale to get average and percent of the score. The quantitative was using Mann-Whitney test to find out the perspective difference and self confidence between both S.Hut forestry and non forestry.

\section{Results and Discussion}

Characteristic of respondent The respondents consisted of 122 S.Hut forestry and 38 S.Hut non forestry. Most of S.Hut forestry worked as bureaucrats and private employees. Bureaucrats work in ministry of forestry and local government. Private employees work in forestry private companies (IUPHHKHT/HA) or forestry consultant. Meanwhile, most of S.Hut non forestry worked in private companies such as plantation companies, mining companies, banking, marketing, and broadcasting media. The average age of the respondents was 25-45 years and dominated by male. Most of the repondents has level education on strata 1 (undergraduated program), with 3 years of working experiences and dominated by S.Hut whose worked in Java Island.

\section{Perspective of forestry graduate understanding on rural forestry business}

1 Commodity identification and market prospect The fineness of forestry business is the diversity of commodity or forest products that can be produced. According to Law Number 41/1999 concerning forestry, forest products are biological, non biological things, and their derivatives as well as services from forest. According to S.Hut, there are 27 types of forest product commodity that is potential to be developed into businesses, that is a panorama of nature, water, carbon storage, rattan, bamboo, honey, medicinal plants, ornamental plants, jelutung, latex of aghatis, gaharu, sugar palm, acacia wood, african wood, jabon, sengon, meranti, teak wood, pine wood, neem wood, sawn compost, bio-energy commodities, forestry seeds, mangrove charcoal, animal, and exotic plant. The kinds of forest product can be classified into 3 groups that is non timber forest products (NTFP), environmental services, and wood (Puspitojati et al. 2014). The non timber forest products are divide into NTFP 1 and 2. NTFP 1 are kinds of include NTFPs important NTPFs according to Permenhut P.21/2009 concerning NTFPs important NTPF. NTFP 2 are kinds of NTFPs that have not been identified by Permenhut P.35/2007 concerning NTPF and it does not include main NTFPs primadonna on Permenhut P.21/2009. Grouping of potential commodities as shown in Table 1. How S.Hut perception regarding the potential commodities at the present and future? Table 2 shows that S.Hut forestry and non forestry had similar perception about current potential products. However, they had different perception in judging future potential commodity. According to S.Hut forestry, current and future commodity that was the most potential NTFP1-wood-environment service. Meanwhile according to S.Hut non forestry, current commodity that was potential was NTFP1-wood-environment service, and future commodity that was potential was NTFP1wood-NTFP 2.

High potential commodity does not necessarily have high opportunity in the market. According to Table 3, generally, the average score of market opportunity for every commodity ranged from 3.1-5.0 (normal-high category) either now or in the future. S.Hut forestry thought that current commodities that had high market opportunity were wood, environment service, and NTFP 1. While S.Hut non forestry believed that 
Table1 Forest product commodity that is potential to be developed into businesses according to S.Hut

\begin{tabular}{ll}
\hline \multicolumn{1}{c}{ Groups } & \multicolumn{1}{c}{ Kind of commodities } \\
\hline Timber & acacia wood, african wood, jabon, sengon, meranti, teak wood, pine wood, and neem wood \\
Environmental service & panorama of nature,water and carbon storage \\
NTFP 1 & rattan, bamboo, getah pinus, jelutung, getah agathis, gaharu, and aren \\
NTFP 2 & honey, medicinal plants, ornamental plants, sawn compost, bioenergy commodities, forestry seeds, \\
& mangrove charcoal, animal breeding, and exotic plants \\
\hline
\end{tabular}

Table 2 The judgement of S.Huts about the potential commodity of NTFP, timber, and environmental services.

\begin{tabular}{lcccc}
\hline & \multicolumn{3}{c}{ Present $^{\mathrm{b}}$} & \multicolumn{2}{c}{ Future $^{\mathrm{b}}$} \\
\cline { 2 - 5 } & $\mathrm{F}^{\mathrm{c}}$ & $\mathrm{NF}^{\mathrm{d}}$ & $\mathrm{F}$ & $\mathrm{NF}$ \\
\hline NTFP 1 & 38.22 & 39.13 & 31.06 & 31.37 \\
Timber & 34.03 & 26.09 & 29.19 & 31.37 \\
Environmental services $^{*}$ NTFP 2 $^{\mathrm{a}}$ & 20.94 & 21.74 & 28.57 & 13.73 \\
\hline
\end{tabular}

${ }^{a}$ Kinds of NTFPs have not been identified by Permenhut P.35/2007 and it does not include main NTFPs primadonna on Permenhut P. $21 / 2009 ;{ }^{b}$ percent of respondents number; ${ }^{\mathrm{c}} \mathrm{S}$. Hut forestry; ${ }^{\mathrm{d}} \mathrm{S}$.Hut non forestry

Table 3 Commodity market opportunities of potential forest products

\begin{tabular}{lccccc}
\hline \multirow{2}{*}{ Commodities } & \multicolumn{3}{c}{ Present $^{\mathrm{a}}$} & \multicolumn{3}{c}{ Future $^{\mathrm{a}}$} & \multirow{2}{*}{ Sig } \\
\cline { 2 - 5 } & $\mathrm{F}^{\mathrm{b}}$ & $\mathrm{NF}^{\mathrm{c}}$ & $\mathrm{F}$ & $\mathrm{NF}$ & \\
\hline Environmental services & 3.75 & 4.30 & 4.04 & 3.86 & 0.42 \\
NTFP 1 & 3.51 & 3.64 & 3.80 & 3.63 & 0.52 \\
Timber & 3.92 & 3.60 & 4.00 & 3.73 & 0.68 \\
NTFP 2 & & & & & \\
\end{tabular}

${ }^{a}$ Kinds of NTFPs have not been identified by Permenhut P.35/2007 and it does not include main NTFPs primadonna on Permenhut P.21/2009; ${ }^{b}$ percent of respondents number; ${ }^{\mathrm{c}} \mathrm{S}$. Hut forestry; ${ }^{\mathrm{d}} \mathrm{S}$. Hut non forestry

environment service, NTFP 2, and NTFP 1 had high market opportunity. In the future, according to S.Hut forestry, commodities that will have market opportunity are NTFP 2, environment service, and wood. Whereas S.Hut non forestry chose environment service, NTFP 2 and wood. The difference of work field did not show significant effect towards the judgement of S.Hut about market opportunity.

2 Relative position of forest business towards other businesses The use of forest area often connects to other business sectors, like plantation and mining. This discussion is intended to know the view of forestry graduates about the position of forest products compared to other business sectors. Figure 1 shows that S.Hut forest and non forest had different point of view in judging the existence of forestry sector business compared to other business sectors. According to S.Hut forest, forestry business was the most interesting business compared to mining and plantation. This business is more friendly environment. Moreover, it can give various advantages and products. Economically the advantages that this business can give is to keep the function of forest. Therefore, they thought that this business must be placed on the first position compared to other businesses.
S.Hut forestry more oriented to environmental conditions than the economic. This different from S.Hut non foresty. The S.Hut non forestry puts their point of view on economic; consequently, they only think about the benefits. The most interesting business is mining and palm oil plantation. These 2 sectors can give very high benefits compared to other businesses.

3 The main actor in rural forestry business The paradigm of forest management has changed into new paradigm, that is, community-based forest management (CBFM). This is no longer based on government (statebased forest management). Forest management done must be intended to improve the welfare of community (Law Number 41 Tahun 1999). Suharjito (2014) said that community must be the main actor of forest management. This is not because the community has the capacity, like knowledge, local institution, adaptation ability, and innovation. Therefore, forestry business developed must accentuate the community around the forest compared to other actors.

S.Hut forestry and non forestry have similar perspective about the main actor in forest business (Figure 2). The majority of S.Hut forestry (55\%) and non forestry $(74 \%)$ thought that in forest business, there was 

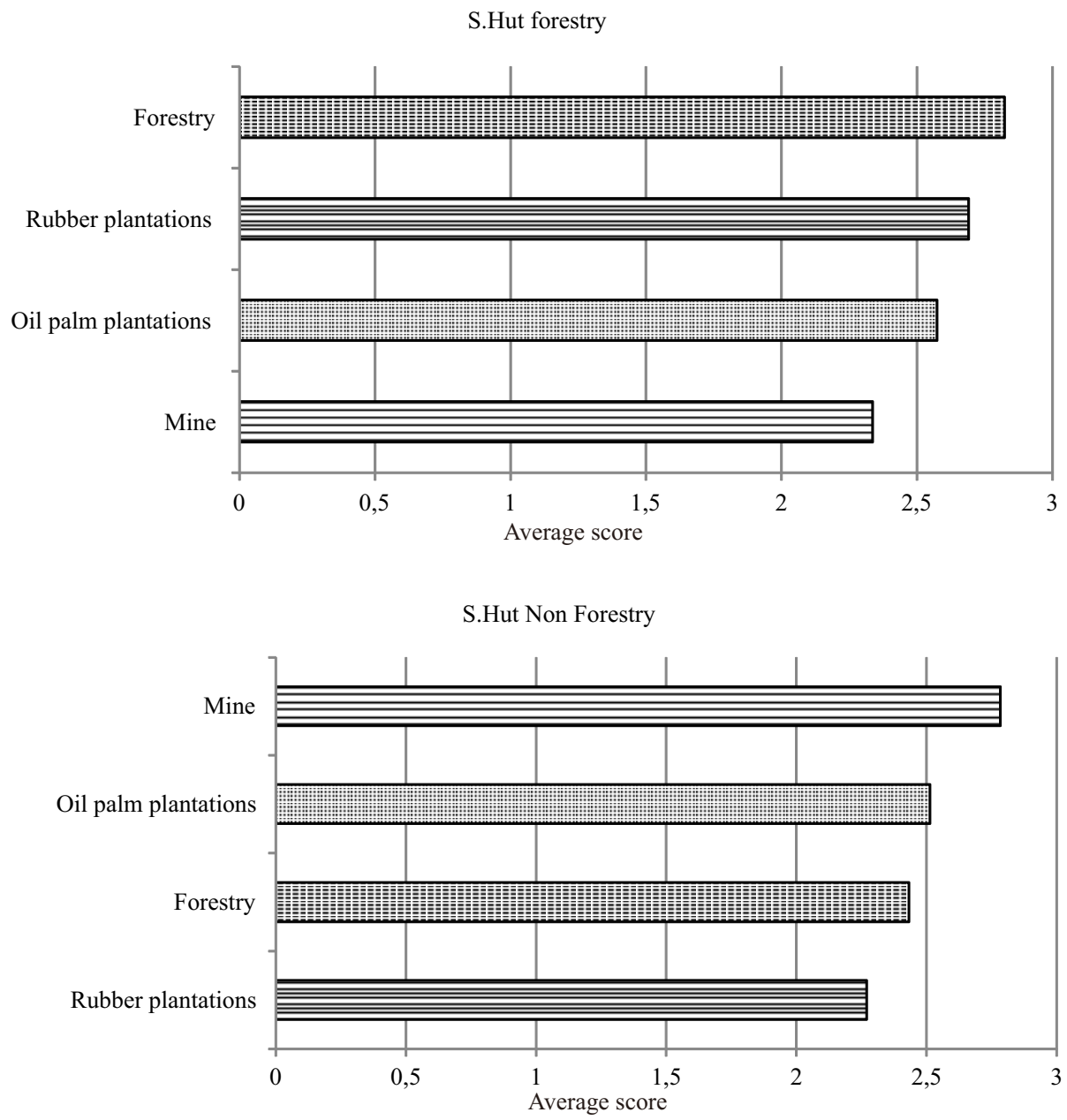

Figure 1 The relative position of forestry businesses to other business.

no actor that must be highlighted. All actors must work together and actively develop the business for community welfare. Other $38 \%$ of S.Hut foresty and $24 \%$ of S.Hut non forestry consider that the main actor must be prioritized was the people. So far, the existing policy and fact has been the majority of forestry business done by investors with a lot of capital. While, the involvement was still low. The point of view from S.Hut was good. The community must be prioritized in the business; however, the community had limitation, like experience-based knowledge, labor, and capital. Meanwhile, the development of science related to this business keeps developing. As a result, the community needs to collaborate with various stakeholders so that the potential of each party in forest business can be optimalized.

4 Business scale The business scale is an ability of companies in managing their business, usually using a benchmark amount of labor and income earned each period. Badan Pusat Statistik (BPS-Statistics Indonesia) divides the business scale into 3 groups according to the amount of labor used that is small scale (5-19 people), medium (20-99 people) and large scale ( $>100$ people) (Tambunan 2009). Forest communities always described as having limitations in science, technology and innovation. These limitations are always seen as factors that cause no growth of small-scale business in forestry (Tambunan 2009). Forestry graduates should know about forestry business scale. If there are 3 actors, namely S.Hut, community and private investors, According to S.Hut is the suitable business scale to be developed by 3 actors? Table 4 shows that business scale can be developed by S.Hut, private investor, and community.

Based on Table 4, S.Hut forestry and non forestry have the same judgement about the business that can be developed by the 3 actors. Forestry graduates are potential human resources in this business because they have enough competence in this field, forestry, compared to the other 2 actors. However, in order to become an entrepreneurs, they have limitation in networking, capital, experience and the spirit of entrepreneurship. Based on the judgement, business scale that is still considered the best for S.Hut is middle business scale. While the private investor has superiority in doing the business because they have a lot of fund, experience, and high spirit of entrepreneurship. This superiority is the strenght that private investors have to be 
able to survive in this business. Furthermore, they have a courage to take the worst risk. Consequently, the business that is suitable for forestry graduates is the big scale business. Meanwhile for the community, the business that is suitable for them is middle and small scale business. This is because the community has limitation in capital, knowledge and the spirit of entrepreneurship. According to Inggarwati and Kaudin (2010), it is difficult to develop business scale because of limited capital and knowledge as well the spirit of entrepreneurship that is owned by the business doers. The community could be able to develop the big scale of business, but if the motivation is low, it can cause reluctance to develope the business. The reluctance is caused by the desire of entrepreneurship in order to retain the ownership or to control the administrative. Moreover, the entreprenuers' concerns will get harder or they can lose their job satisfaction. If the spirit of entrepreneurship possessed by the community is strong, limitations they have will not stop.

Rural economic activities based on forest ecosystem are worth to do. However, the business is still regarded as a side business, and this has not been used as the main source of people's livelihood. Forestry graduates have optimism or confidence that the scale of the business carried out by the public can still be upgraded to a larger scale (Table 5). These conditions can be created with an attempt to overcome the

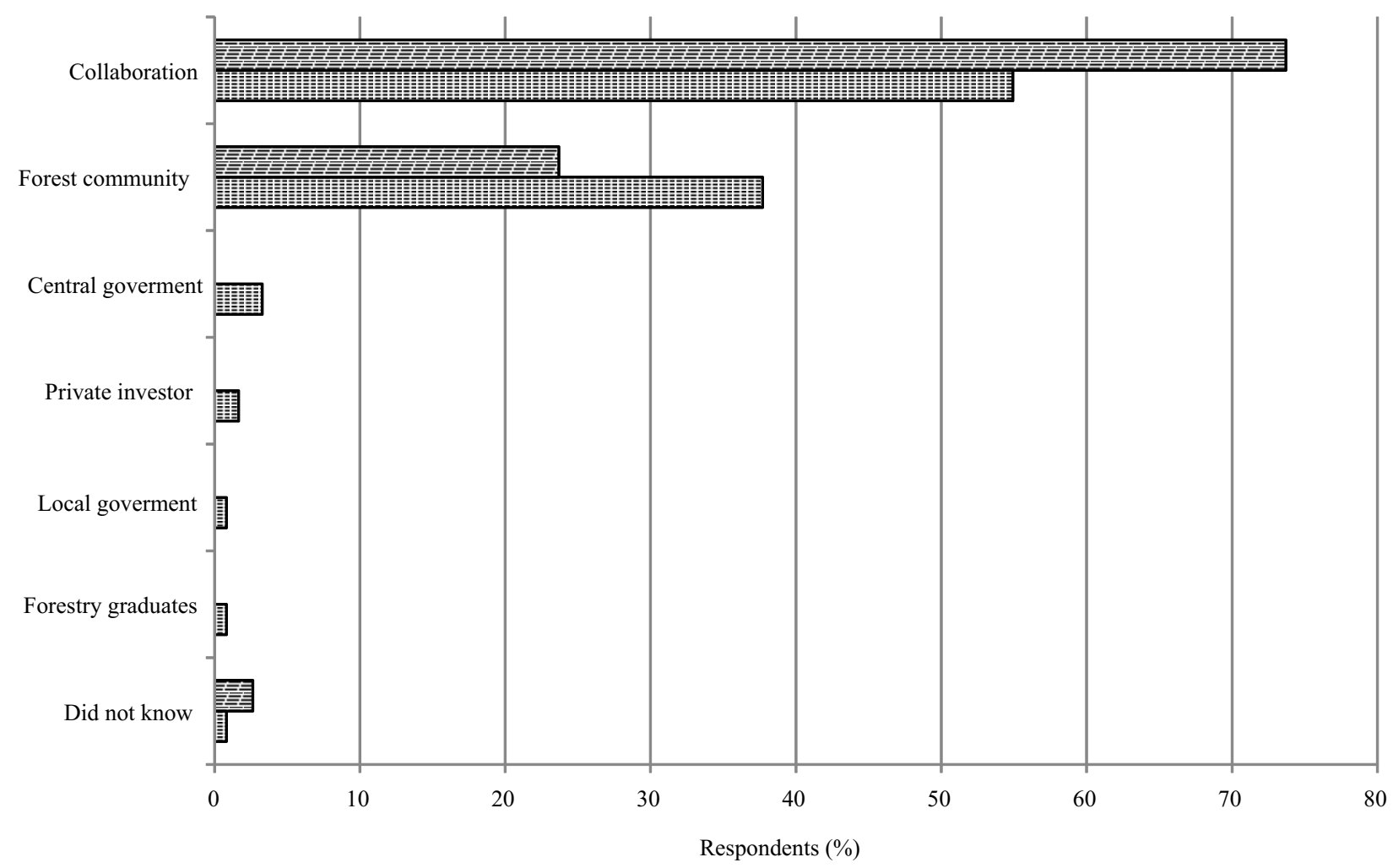

Figure 2 The main actors in forest business. S.Hut non-forestry (国), S.Hut forestry (国).

Table 4 Assessment of business scale for S.Hut, private investors, and the community

\begin{tabular}{|c|c|c|c|}
\hline \multirow{2}{*}{ Actor } & \multicolumn{2}{|c|}{ Average score } & \multirow{2}{*}{ Note } \\
\hline & $\mathrm{F}^{\mathrm{a}}$ & $\mathrm{NF}^{\mathrm{b}}$ & \\
\hline S.Hut & 2,2 & 2,2 & medium \\
\hline Private investor & 2,5 & 2,5 & large \\
\hline Community & 1,9 & 2,2 & small and medium \\
\hline
\end{tabular}

${ }^{\mathrm{a}} \mathrm{S}$.Hut forestry; ${ }^{\mathrm{b}} \mathrm{S}$.Hut non forestry
Table 5 Optimism of S.Hut to increase the scale of business

\begin{tabular}{lll}
\hline \multirow{2}{*}{ Respon } & \multicolumn{2}{c}{ Proportion (\%) } \\
\cline { 2 - 3 } & $\mathrm{F}^{\mathrm{a}}$ & $\mathrm{NF}^{\mathrm{b}}$ \\
\hline Very optimistic & 20.83 & 26.32 \\
Optimistic & 22.50 & 13.16 \\
Quite optimistic & 35.00 & 34.21 \\
Not optimistic & 16.67 & 18.42 \\
Very not optimistic & 5.00 & 7.89 \\
\hline${ }^{\mathrm{a}}$ S.Hut forestry; ${ }^{\mathrm{b}}$ S.Hut non forestry
\end{tabular}


limitations in the community.

These limitations can be overcome through cooperation or collaboration with relevant stakeholders, one of which is S.Hut. According to Laws and Regulations Number 20/2008 on Micro, Small and Medium Enterprises, a partnership is defined as cooperation in the business relationship, either directly or indirectly, on the basis of the mutual need, trust, strengthen and prosper involving various parties. Partnership is carried out with pattern: plasma core, subcontract, franchise, general trade, distribution, and agency as well as other forms of partnerships, such as profit sharing, operational cooperation, and joint venture (JV). If S.Huts are given the opportunity to be entrepreneurs, will they have the willingness to cooperate with the community? Based on Table 6, both S.Hut forestry and non forestry showed a fairly positive preference to collaborate with society.

An important reason to cooperate with the community (Table 7):

1 The majority of forest communities was classified into poor communities so that collaborating with the community could help improve the welfare (29.75\%),

2 The society was the potential resource in forestry business. It could be used as a source of labor and land providers (14.56\%),

3 Society was the catalyst for sustainable forestry business. With the involvement of the community, business security would be assured of and it could reduce conflicts $(27.85 \%)$,

4 It could be used to develop enterprises (6.33\%), and 5 Community was the main actor that should be prioritized $(3.80 \%)$.

Based on these results, it can be seen that most forestry graduates considered forest communities only as the objects, and the rests (only a small precentage) considered communities as the main actor. Patterns of cooperation is one of innovations, so cooperation formed should be able to provide a new thing. The form of cooperation that can be done with the society is profit sharing and the workforce. Profit sharing is a fair business result sharing on the basis of mutual agreement.

The perspective of forestry graduates towards self potential The perspective of S.Hut towards self potential which is reviewed from self assessment concerning the level of interest to become entrepreneurs; their interest towards primary and secondary business; knowledge and capacity they have to develop business (Table 8).

Interest is motivation coming from the existence of forestry businesses which can create interest in S.Hut to be someone who has the courage to take risks and open a business so that this can create economic growth in forest communities (Zimmerer 2005; Kasmir 2006; Setiawan 2014). Table 8 shows that the level of interest owned by S.Hut forestry and non forestry was significantly different (0.00). The level of interest in doing business owned by S.Hut forstry was higher than that of S.Hut non forestry. The reasons why S.Huts were interested in becoming entrepreneurs in forestry were: 1) a great advantage because of the price of expensive wood, 2) a variety of forest products, 3) part of Indonesian culture, 4) the improvement of forest community income, 5) in line with field science, 6 ) broad market, 7) simple businesses, 8) abundant resources and 9) future savings. While there were some reasons why S.Huts were not interested, namely: 1) more interested in running other business because the advantages could be obtained quickly and did not need much money to open the business, 2) forestry business had a very high risk; if it is well taken care of, the benefit will be great at the end, but the business could fail before the benefit was obtained due to pests and diseases, 3) forestry enterprises was too complicated, 4) there was no time and wanted to focus work

Table 6 The willingness of forestry graduates to collaborate with the community

\begin{tabular}{lrr}
\hline \multirow{2}{*}{ Willingness to collaborate } & \multicolumn{3}{c}{ Respondent (\%) } \\
\cline { 2 - 3 } & $\mathrm{F}^{\mathrm{a}}$ & $\mathrm{NF}^{\mathrm{b}}$ \\
\hline Yes & 97 & 100 \\
No & 3 & 0 \\
\hline
\end{tabular}

${ }^{a}$ S. Hut forestry; ${ }^{b}$ S. Hut non forestry

Table 7 Reasons to collaborate with the community

\begin{tabular}{lr}
\hline Reason & Respondent (\%) \\
\hline Positive reason & 29.75 \\
\hline Community empowerment to improve the welfare of society & 14.56 \\
Community is the potential business capital as the labors and land providers & 27.85 \\
For the sake of security and business continuity (reducing conflict) & 6.33 \\
For business development & 3.80 \\
The main actors & 0.63 \\
\hline Negative reason & 0.63 \\
\hline The community is only as employees not partners (complicated to have partnership with the & 16.46 \\
\hline community & 100 \\
The forest community is too complicated now. They have been influenced by practical geopolitic & \\
Do not give a reason & Total \\
\hline
\end{tabular}


Table 8 Self potential assessment to become an entrepreneur

\begin{tabular}{|c|c|c|c|c|c|c|c|}
\hline \multirow{2}{*}{ Self assessment } & \multicolumn{5}{|c|}{ Respondent (\%) } & \multirow{2}{*}{$\begin{array}{l}\text { Average } \\
\text { score }\end{array}$} & \multirow{2}{*}{ Sig } \\
\hline & $5^{\mathrm{a}}$ & 4 & 3 & 2 & $1^{\mathrm{b}}$ & & \\
\hline \multicolumn{8}{|l|}{ Interest } \\
\hline a. S.Hut-forestry & 25.83 & 35.83 & 25.00 & 10.00 & 3.33 & 3.71 & 0.00 \\
\hline b. S.Hut-non forestry & 13.16 & 21.05 & 39.47 & 18.42 & 7.89 & 3.13 & \\
\hline \multicolumn{8}{|l|}{ Primary business interest } \\
\hline a. S.Hut-forestry & 18.33 & 29.17 & 25.83 & 20.00 & 6.67 & 3.33 & 0.88 \\
\hline b. S.Hut-non forestry & 23.68 & 21.05 & 28.95 & 21.05 & 5.26 & 3.40 & \\
\hline \multicolumn{8}{|l|}{ Secondary business interest } \\
\hline a. S.Hut-forestry & 16.67 & 27.50 & 35.00 & 17.50 & 3.33 & 3.40 & 0.76 \\
\hline b. S.Hut-non forestry & 0.00 & 47.37 & 36.84 & 10.53 & 5.26 & 3.33 & \\
\hline \multicolumn{8}{|l|}{ Knowledge } \\
\hline a. S.Hut-forestry & 7.83 & 32.17 & 52.17 & 6.09 & 1.74 & 3.38 & 0.16 \\
\hline b. S.Hut-non forestry & 2.78 & 22.22 & 55.56 & 19.44 & 0.00 & 3.08 & \\
\hline \multicolumn{8}{|l|}{ Capacity } \\
\hline a. S.Hut-forestry & 9.09 & 29.75 & 47.93 & 9.92 & 3.31 & 3.30 & 0.11 \\
\hline b. S.Hut-non forestry & 5.41 & 13.51 & 59.46 & 18.92 & 2.70 & 3.10 & \\
\hline
\end{tabular}

${ }^{\mathrm{a}}$ positive respondent, ${ }^{\mathrm{b}}$ negative respondent

on the current position and 5) it took two times to start the business.

Interest towards business is not the guarantee for someone to become an entrepreneur if it is not accompanied by strong will. Interest to become an entrepreneur can be driven by two factors: the positive factor (pull factor) and negative factor (push factor). Positive factor is that a person is interested in becoming an entrepreneur because of the desire arising from himself (doing business as a life choice). While the negative factor is the interest to establish a business driven by several pressures, for example: trouble to find jobs, not enough salaries, no special skills in other areas, discrimination, conflict in the workplace and job loss (Inggarwati \& Kaudin 2010). Forest ecosystem-based rural businesses that can be developed is the primary and secondary business. Table 8 shows that the assessment of S.Hut concerning primary and secondary business interests was not significantly different. However, when viewed from the value of the average score given, S.Huts forestry were more interested in running a secondary business. While S.Huts non forestry were more attracted to the primary business. The high interest of S.Hut forestry to secondary business was due to: high uncertainty of primary business and high risk of failure. Moreover, the secondary business had high selling value and the secondary business was more easily managed with simple planning. While S.Huts non forestry were more interested in the primary business because primary business was easy to do and did not require high technology (according to culture) while the secondary business needed high technology terribly (more orientation to the pulp and paper). The tools used were high-tech tools that came from abroad. The price of the tool was very expensive and it required special skills to apply; however, the capacity of the existing human resources was still very limited. At the moment, of 120 S.Huts forestry and 38 S.Huts non forestry, only $21 \%$ and $13 \%$, that are running the business. The business carried out was the primary business in the form of community forests and nurseries. The business was a side business, trial business without careful planning. According to Kashmin (2006), trying to run a business is an initial principal to become entrepreneurs.

When a person has a high level of attraction and interest of doing business, it must be supported by a knowledge of the business and the capacity to run the business. Knowledge is a person's capacity to understand and interpret the results of observation and experience as the basis to make decision (Sunaryo \& Joshi 2003). While capacity is the level of ability to do something optimally. The capacity of forestry graduates to run business means that they have the ability and the capability to do business. The level of knowledge and capacity owned was analyzed by using the theory of selfefficacy in order to know S.Huts' beliefs concerning their knowledge towards the business and their belief in capacity to run the business. The knowledge owned (Table 8 ) by S.Huts forestry and non forestry was not significantly different. Both respondents believed that their knowledge of business was quite good. The same response was viewed based on the belief of self capacity in which 2 respondents felt quite capable and able to run the business.

Performance of rural forestry business Generally the rural forestry business had shown good economic feasibilty and worthed to develop in the rural economy. However that income is still not able to improve the standard of living worthy. The average income earned from rural forestry 
business is IDR384,152 per capita a month (Table 9), that income is still low if compared to the standard poverty line according to the BPS (2015) and the World Bank (2012). The poverty line standard according to BPS is IDR530,958 per capita per a month, while the World Bank is $\$ 1<\mathrm{P}<\$ 2.25$ from value of purchasing power parity (PPP) per capita per day, equivalent to IDR1,593,840<P $<$ IDR3,586,140 per capita a month on condition \$1 PPP is IDR53,128 per capita per day.

If the income from the rural forestry business as compared with income of oil palm farmers and salary of S.Hut as in Table 10, then income from the rural forestry business is a lowest. While the salary of S.Hut is the highest incomes. The income of S.Hut will be increasing along with the increase in work experience. The income of S.Hut non forestry is higher than S.Hut forestry. Based on these conditions, the rural forestry business faced 2 major challenges namely S.Hut has a high opportunity to to work in other sectors and rural forestry businesses have long grace period (1 cycle). The high opportunity of S.Hut in the world of work that supported by high income would cause S.Hut glad to be workers than entrepreneur. The long grace period in rural forestry business, rationally will be reducing the attractiveness of forestry business. The effect of the grace period causing income will be obtained when the end of the cycle. While, S.Hut need income in the short term to fulfill their needs, even though income from work earned is low, S.Hut tend to retain the jobs than be entrepreneurs.
The attractiveness increase of rural forestry businesses can be done with increasing profitability of rural forestry business. It is important to change the rural forestry business become a major source of income and which can be improve welfare for the community. Increased of profitability could be with the development of business scale, land intensification and diversification of commodities. In order to create those conditions, we need qualified forestry human resource, one of which is S.Hut. hus, there needs to be space in the form of policies and incentives for S.Hut to become entrepreneurs. Policies and incentives that may be referred to the provision of access to land and access to land use development. Development of land use can be done by applying multiple use systems such as agroforestry, in order to obtain a quick profit in the short term and long term.

\section{Conclusion}

Forestry graduates are potential to be entrepreneurs in forestry field. This study found out that the S.Hut in Indonesia had ample or good perspectives based on the parameters of higher interests, attractiveness, knowledge, and effications. It mean that they were worthed to be involved as the business entrepreneurs. Moreover, policy is needed to give access and a good environment to do forest ecosystem business in rural areas.

\section{Recommendation}

1 Education Institution: entrepreneurship course is needed

Table 9 Financial performance of rural forestry business

\begin{tabular}{lcccc}
\hline \multicolumn{1}{c}{ Pattern of utilization } & $\begin{array}{c}\text { Area } \\
(\text { ha household }\end{array}$ & $\begin{array}{c}\text { Income (IDR } \\
\text { household }^{-1} \text { month }^{-1} \text { ) }\end{array}$ & $\begin{array}{c}\text { Income (IDR } \\
\text { capita }^{-1} \text { year }^{-1} \text { ) }\end{array}$ & $\begin{array}{c}\text { Income (IDR } \\
\text { capita }^{-1} \text { year }^{-1} \text { ) }\end{array}$ \\
\hline Monocultur & 1.06 & 450,506 & 112,626 & $1,351,518$ \\
Mix cropping & 1.22 & $2,011,781$ & 502,945 & $6,035,344$ \\
Simple agroforestry & 1.65 & $2,528,145$ & 632,036 & $7,584,434$ \\
Agroforestry complex & 1.15 & $1,156,007$ & 289,002 & $3,468,021$ \\
\hline Average & 1.27 & $1,536,610$ & 384,152 & $4,609,829$ \\
\hline
\end{tabular}

Table 10 Comparison of income between the forest community, oil palm farmers and S.Hut

\begin{tabular}{lc}
\multicolumn{1}{c}{ Category } & Income (IDR capita month $^{-1}$ ) \\
\hline Forest community & 384,152 \\
Oil palm farmers & $1,188,360$ \\
Salary of S.Hut forestry & \\
a. Work experience $<10$ years & $4,944,020$ \\
b. Work experience $>10$ years & $7,445,519$ \\
Salary of S.Hut non forestry & \\
a. Work experience $<10$ years & $6,205,882$ \\
b. Work experience $>10$ years & $8,909,091$ \\
\hline
\end{tabular}


in forest sector which is more relevant and attractive. This is very important to change the mindset and motivate to do business.

2 Government: forestry graduates needs space to become entrepreneurs in forest sector with various businesses.

\section{Acknowledgment}

Our sincere appreciation is extended to the Provincial Government of West Java Province for the funding supports on this research and all forestry graduates throughout Indonesia for their kindness in taking part of being respondents in this study.

\section{References}

Achmad B, Purwanto R. 2014. Peluang Adopsi Sistem Agroforestri Dan Kontribusi Ekonomi Pada Berbagai Pola Tanam Hutan Rakyat Di Kabupaten Ciamis. Jurnal Bumi Lestari 14(1):15-26

Andrew O, Omobude E. 2011. An analysis of a typical rural economy in Nigeria and its connection to climate change adaptation. Journal of Environmental Management and Safety 2(2):111-121

Bandura A. 1986. The explanatory and predictive scope of self-efficacy theory. Journal of Social and Clinical Psychology 4(3):359-373. http://dx.doi.org/10.1521/ jscp.1986.4.3.359.

Baron R, Byrne D. 2000. Social Psychology. 9th Edition. Massachusetts: Allyn \& Bacon.

[BPS] Badan Pusat Statistik. 2015. Jumlah dan Persentase Penduduk Miskin, Garis Kemiskina, Indeks Kedalaman Kemiskinan (P1) dan Indeks Keparahan Kemiskinan (P2) Menurut Provinsi Tahun 2013-2014. [diunduh pada 2015 Mei 18]. Tersedia pada:http://www.bps.go.id/link TabelStatis/view/id/1488

Brown L, Malouff J, Schutte. 2005. The effectiveness of a self-efficacy intervention for helping adolescents cope with sport-competition loss. Journal of Sports Behaviour 28(2):136-150

Darusman D. 2012. Kehutanan Demi Keberlanjutan Indonesia. Bogor: IPB Press.

[DPKHA, IPB] Direktorat Pengembangan Karir dan Himpunan Alumni, Institut Pertanian Bogor. 2012. Tracer Study Himpunan Alumni 2012. Bogor: Institut Pertanian Bogor.

Galoway L, Kelly S. 2009. Identifying entrepreneurial potential? An investigation of the identifiers and features of entrepreneurship. International Review of Entrepreneurship. Ukraina: Senate Hall Academic Publishing

Hardjanto. 2003. Performance and development of small scale private owned timber business in Java Island [dissertation]. Bogor: Bogor Agricultural University.

Hardjanto, Hero Y, Trison S. 2012. Institutional design on people forest to establish forest and business sustainability in order to poverty alleviation in rural communities. Jurnal Ilmu Pertanian Indonesia 17(2):103-107

Hossain M. 2000. Transformation of Asian rural Economy: The Chao Phraya Delta: Historical Development, Dynamics and Challenges of Thailand's Rice Bowl. International Conference of Kasetsart University 12-15 December 2000. Bangkok: Kasetsart University.

Ilham M. 2012. The effect of family, education, and social environment towards entrepreneurship spirit and interest [thesis]. Bogor: Bogor Agricultural University.

Inggarwati K, Kaudin A. 2010. Peranan faktor-faktor individual dalam mengembangkan usaha studi kuantitatif pada wirausaha kecil di Salatiga. Jurnal Manajemen Bisnis 3(2):185-202.

Kasmir. 2006. Kewirausahaan. Jakarta: PT. Raja Grafindo Persada.

[MoF] Ministry of Forestry. 2011. Rencana Kehutanan Tingkat Nasional 2011-2030. Jakarta: Ministry of Forestry.

Nimalathasan B, Achchuthan S. 2013. Relationship between entrepreneurial motivation and entrepreneurial Intention: A case study of management undergraduates of The University of Jaffna, Sri Lanka. In: Proceeding of the 9th International Conference on Business Management, Turning Crisis into Opportunities: Meeting the Unmet; Sri Lanka; March 1, 2013. Pp.42-50

Nishantha B. 2008. Influence of personality traits and sociodemographic background of undergraduate students on motivation for entrepreneurial career: The case. of Sri Lanka. Ryukoku Journal of Economic Studies. 49(2):71-82

Praswati A. 2014. Analiyzes the factors that influence entrepreneurial interest among university students. Sancall 2014. Research Methods and Organizational Studies. 134-142.

Puspitojati T, Mile M, Fauziah E, Darusman D. 2014. Hutan Rakyat Sumbangsih Masyarakat Pedesaan untuk Hutan Tanaman. Bahruni, editor. Yogyakarta: PT. Kanisius.

Rochmayanto Y, Supriadi R. 2012. Economic scale of smallholders pulpwood plantation in Kuantan Singingi Distric, Riau Province. Jurnal Penelitian Sosial dan Ekonomi Kehutanan.9(2):87-95.

Salaka F, Nugroho B, Nurrochmat D. 2012. Marketing policy strategy for non timber forest products in West Seram Regency, Maluku Province. Jurnal Analisis Kebijakan Kehutanan 9(1):50-65.

Setiawan. 2014. Kamus Besar Bahasa Indonesia. Jakarta: Badan Pengembangan dan Pembinaan Bahasa, Kementerian Pendidikan dan Kebudayaan.

Suharjito D. 2014. Orasi Ilmiah Guru Besar IPB: Devolusi Pengelolaan Hutan dan Pembangunan Masyarakat Pedesaan disampaikan pada 3 Mei 2014. Bogor: IPB Press.

Suharti L, Sirine H. 2011. Faktor-Faktor yang berpengaruh 
terhadap niat kewirausahaan (Entrepreneurial intention) (Studi terhadap Mahasiswa Universitas Kristen Satya Wacana, Salatiga). Jurnal Manajemen dan Kewirausahaan 13(2):124-134.

Suhendang E. 2013. Perkembangan Paradigma Kehutanan. Makalah disampaikan dalam Diskusi Pengelolaan Hutan Berbasis Ekosistem sebagai Pendekatan untuk Pengelolaan Hutan Indonesia dalam Paradigma Kehutanan Indonesia Baru: 2013 Agustus 20. Bogor: Institut Pertanian Bogor.

Sunaryo, Joshi L. 2003. Peranan Pengetahuan Ekologi dalam Sistem Agroforestri. Bogor: World Agroforestry Center (ICRAF).

Storey G. 1910. The Theory and Practice of Perspective. New York: Oxford At The Claredon Press.

Tambunan T. 2009. UMKM di Indonesia. Bogor: Ghalia Indonesia
Thung C. 2014. Faktor pra-natal dan post-natal sebagai determinan profesi wirausaha: studi kasus di Indonesia. AGORA 2(1):595-600.

World Bank. 2012. Targeting Poor and Vulnerable Households in Indonesia. Jakarta: The World Bank.

Wulandari C, Budiono P, Yuwono S, Herwanti S. 2014. Adoption of agroforestry pattern and crop system around Register 19 Forest Park, Lampung Province, Indonesia. Jurnal Manajemen Hutan Tropika 20(2):86-93. http://dx.doi.org/10.7226/jtfm.19.2.86.

Wurangian K, Putra E. 2013. The feasibility study of community forest nursery in North Sulawesi. Info BPKManado 3(1): 23-36.

Zimmerer. 2005. Essentials of Entrepreneurship and Small Business Management. New Jersey: Pearson Prentice Hall. 